\title{
COOLING MODIFIES MIXED MEDIAN AND ULNAR PALMAR STUDIES IN CARPAL TUNNEL SYNDROME
}

\author{
Rogério Gayer Machado de Araújo', João Aris Kouyoumdjian²
}

\begin{abstract}
Temperature is an important and common variable that modifies nerve conduction study parameters in practice. Here we compare the effect of cooling on the mixed palmar median to ulnar negative peak-latency difference (PMU) in electrodiagnosis of carpal tunnel syndrome (CTS). Controls were 22 subjects ( 19 women, mean age 42.1 years, 44 hands). Patients were diagnosed with mild symptomatic CTS ( 25 women, mean age 46.6 years, 34 hands). PMU was obtained at the usual temperature, $>32^{\circ} \mathrm{C}$, and after wrist/hand cooling to $<27^{\circ} \mathrm{C}$ in ice water. After cooling, there was a significantly greater increase in PMU and mixed ulnar palmar latency in patients versus controls. We concluded that cooling significantly modifies the PMU. We propose that the latencies of compressed nerve overreact to cooling and that this response could be a useful tool for incipient CTS electrodiagnosis. There was a significant latency overreaction of the ulnar nerve to cooling in CTS patients. We hypothesize that subclinical ulnar nerve compression is associated with CTS.
\end{abstract}

KEY WORDS: carpal tunnel syndrome, nerve conduction studies, median nerve, temperature, ulnar nerve.

\begin{abstract}
Influência do resfriamento nos parâmetros de condução nervosa mista do mediano e ulnar na síndrome do túnel do carpo

RESUMO - Temperatura é uma variável comum e importante que modifica os parâmetros de condução nervosa na prática eletrodiagnóstica. Neste trabalho nós estudamos o efeito do esfriamento na diferença de latências palmares entre o nervo mediano e ulnar (PMU), segmento palma-pulso, utilizada rotineiramente para o eletrodiagnóstico da síndrome do túnel do carpo (STC). Foram estudados 22 controles (19 mulheres, média de idade 42,1 anos, 44 mãos) e 25 pacientes ( 25 mulheres, média de idade 46,6 anos, 34 mãos) com diagnóstico de STC leve. PMU foi obtida em temperatura usual $\left(>32^{\circ} \mathrm{C}\right)$, e após resfriamento de mão/ pulso em água com gelo $\left(<27^{\circ} \mathrm{C}\right)$. Após o resfriamento houve aumento significativo na PMU e na latência mista palmar do nervo ulnar nos pacientes quando comparados aos controles. Nós concluímos que o resfriamento modifica significativamente a PMU e propomos que as latências obtidas em nervos submetidos à compressão reagem de maneira mais acentuada ao frio e isso poderia ser uma arma útil para o eletrodiagnóstico da STC incipiente. Da mesma forma, houve reação mais acentuada ao frio no estudo da latência mista palmar do nervo ulnar nos pacientes mas não nos controles, que poderia levantar a hipótese de compressão subclínica do nervo ulnar.
\end{abstract}

PALAVRAS-CHAVE: síndrome do túnel do carpo, condução nervosa, nervo mediano, temperatura, nervo ulnar.

Carpal tunnel syndrome (CTS) is the most common entrapment neuropathy of the upper limbs ${ }^{1,2}$. In the Netherlands, the prevalence is $5.8 \%$ in women and $0.6 \%$ in men $^{3}$, and in Southern Sweden, the prevalence is $2.7 \%{ }^{4}$. Nerve conduction studies (NCS) are the most important, useful, and rapid tool for diagnosis of CTS, mainly in mild cases ${ }^{5}$. In the last decade several new methods for NCS have been incorporated into CTS electrodiagnosis; comparison of median sensory or mixed latencies of the ulnar or radial nerves in the same limb has become a very common practice $^{6}$. In theory, person to person variability in conduction velocity, due to age and genetic differ- ences, can be controlled for by comparing nerve conduction velocity between nerves in the same limb? Temperature is one of the most important factors influencing nerve conduction parameters ${ }^{8-11}$. Lowering the temperature prolongs the open time of voltagegated sodium channels, thereby generating a larger and longer action potential ${ }^{12}$. Latency, amplitude, duration, and area of sensory nerve action potentials and compound muscle action potentials increase with decreasing temperature.

Robinson et al. ${ }^{13}$ reported that a combined sensory index (CSI), the sum of three nerve latency differences, is better than a single test for diagnosing

Neuromuscular Investigation Laboratory, Department of Neurological Sciences, Faculdade de Medicina de São José do Rio Preto, São José do Rio Preto SP, Brazil (FAMERP): ${ }^{1} \mathrm{MD}$, Postgraduate Student; ${ }^{2} \mathrm{MD}$, PhD, Professor of Neurology.

Received 26 January 2007, received in final form 9 April 2007. Accepted 30 May 2007. 
CTS. Their experience suggests that latency differences between nerves in the same digit or hand are not markedly affected by cold. In a later study, Lew et al. ${ }^{14}$ investigated the effect of temperature on absolute latencies and latency differences and concluded that temperature had no significant effect on latency differences or the CSI. However, more recently, Kouyoumdjian et al. ${ }^{15}$ showed that cooling does modify latency differences and the CSI.

The aim of this study was to determine if hand cooling below the usual temperature $\left(>32^{\circ} \mathrm{C}\right)$ modifies mixed palm median to ulnar latency differences.

\section{METHOD}

Subjects - From January to December 2005, we prospectively studied two groups of subjects. Controls were individuals without any known systemic disease or symptoms of CTS. Patients were selected from our EMG laboratory and had an electrophysiologically confirmed diagnosis of symptomatic CTS, including hand paraesthesia, numbness, and pain mainly at night. The number of cases and hands, age, gender, body mass index (BMI, weight in kilograms/height ${ }^{2}$ in meters), and wrist index ( $\mathrm{Wl}$, wrist depth/wrist width in millimeters) are shown on Table 1. Individuals with previous CTS surgery and clinical or electrophysiological evidence of polyneuropathy were excluded.

Nerve conduction studies - A Portable Keypoint electromyograph (Medtronic Inc.) was used for all NCS. Midpalmar temperature was controlled using an infrared thermometer (Infrascan, La Crosse Technology, Wisconsin) with a resolution of $0.1^{\circ} \mathrm{C}$ and variation from $-20^{\circ} \mathrm{C}$ to $300^{\circ} \mathrm{C}$. Electrodiagnosis of CTS was based on data obtained from the second review of the American Association of Electrodiagnostic Medicine ${ }^{6}$. Median nerve distal antidromic sensory latency (wrist to index finger, $14 \mathrm{~cm}$ ) was defined as abnormal when $\geq 3.7 \mathrm{~ms}$, negative peak-measured. Mixed palmar median to ulnar nerve latency difference (PMU, palm to wrist, $8 \mathrm{~cm}$ ) was considered abnormal when $\geq 0.30$ $\mathrm{ms}$, negative peak-measured. Median motor nerve distal latency (wrist to APB, $8 \mathrm{~cm}$ ) was considered abnormal when $\geq 4.25 \mathrm{~ms}$. Nerve conduction was normal in all other nerves studied, including the antidromic sensory ulnar and radial, and ulnar motor nerves. For electrodiagnosis of mild CTS, three additional techniques were used: antidromic senso-

Table 1. Epidemiologic data of controls and CTS patients.

\begin{tabular}{ccc}
\hline & Controls & CTS \\
\hline $\mathrm{n}$ & 22 & 24 \\
Hands & 44 & 34 \\
Gender & $19 \mathrm{~F} / 3 \mathrm{M}$ & $24 \mathrm{~F}$ \\
Age & $42.1 \pm 5.1$ & $46.6 \pm 7.5$ \\
BMI & $23.5 \pm 4.1$ & $27.5 \pm 3.5$ \\
WI & $0.684 \pm 0.034$ & $0.712 \pm 0.054$ \\
\hline
\end{tabular}

$\mathrm{n}$, number; CTS, carpal tunnel syndrome; F, female; M, male; BMI, body mass index; WI, wrist index. ry median/ulnar nerve latency difference (ringdiff, wrist to ring finger, $14 \mathrm{~cm}$ ), considered abnormal when $\geq 0.50 \mathrm{~ms}$, negative peak-measured; antidromic sensory median/radial nerve latency difference (thumbdiff, wrist to thumb, 10 $\mathrm{cm}$ ), considered abnormal when $\geq 0.50 \mathrm{~ms}$, negative peakmeasured; $\mathrm{CSI}^{13}$, the sum of PMU, ringdiff, and thumbdiff, considered abnormal if $\geq 1.10 \mathrm{~ms}$.

Temperature control - Patients and controls were electrophysiologically examined using the techniques described above. Electrophysiological parameters were obtained at the usual temperature for electrophysiological diagnosis $\left(>32^{\circ} \mathrm{C}\right)$ and after wrist and hand cooling in ice water to a temperature below $27^{\circ} \mathrm{C}$. The mean latency increase (ms) for each $1^{\circ} \mathrm{C}$ temperature reduction was calculated with the assumption of a linear correlation between temperature reduction and latency increase $\mathrm{e}^{10,11,16}$.

Data analysis - The $t$-test was used to compare median and ulnar nerve latencies and the difference between them obtained at the two temperatures. $P \leq 0.05$ was considered significant.

Ethics - The local ethics committee approved the protocol, and all studies were performed after informed consent had been obtained.

\section{RESULTS}

Nine hands has abnormal median distal sensory latency ( $\geq 3.7 \mathrm{~ms}$, range 3.7 to $4.4 \mathrm{~ms}$ ); 19 hands had abnormal palmar median latency ( $\geq 2,3 \mathrm{~ms}$, range 2.3 to $2.9 \mathrm{~ms}$ ); 33 hands had abnormal PMU ( $\geq 0.3$ $\mathrm{ms}$, range 0.30 to $1.64 \mathrm{~ms}$ ); and, finally 1 hand had abnormal CSI ( $\geq 1.10 \mathrm{~ms}$ ). These electrophysiological findings well defined mild CTS.

There was no temperature $\left({ }^{\circ} \mathrm{C}\right)$ difference between both groups (controls and CTS) under usual temperature and after cooling. For median palm latencies we obtained $32.3 \pm 0.6$ in controls versus $33.0 \pm$ 0.8 in CTS and $21.6 \pm 1.8$ in controls versus $21.6 \pm 2.0$ in CTS. For ulnar palm latencies we obtained $32.3 \pm 0.5$ in controls versus $32.7 \pm 0.7$ in CTS and $21.7 \pm 1.9$ in controls versus $21.7 \pm 1.9$ in CTS.

The median and ulnar sensory distal peak latencies and median and ulnar palmar peak latencies obtained at the two temperatures are shown in Table 2. The results show an increase in mean PMU after cooling in both controls and CTS patients. The mean PMU increase was $0.11 \pm 0.14$ ms in controls and $0.39 \pm$ $0.18 \mathrm{~ms}$ in CTS patients. There was a highly significant difference between two groups in mean PMU increase $(p<0.0001)$.

Also remarkable was the relative increase in ulnar palmar latency after cooling in CTS patients versus controls. The ulnar palmar latency increased to 
Table 2. Negative peak latency (ms) increases (mean and SD) after cooling in controls (44 hands) and CTS patients (34 hands).

\begin{tabular}{|c|c|c|c|c|c|}
\hline & & & $\begin{array}{c}>32^{\circ} \mathrm{C} \\
\text { Latency }\end{array}$ & $\begin{array}{c}<27^{\circ} \mathrm{C} \\
\text { Latency }\end{array}$ & $\begin{array}{c}\text { Mean } \\
\text { increase }\end{array}$ \\
\hline \multirow[t]{2}{*}{ Median } & W-2 & Controls & $2.80 \pm 0.20$ & $4.00 \pm 0.50$ & 1.20 \\
\hline & & CTS & $3.50 \pm 0.30$ & $4.90 \pm 0.60$ & 1.40 \\
\hline \multirow[t]{2}{*}{ Ulnar } & W-5 & Controls & $2.50 \pm 0.20$ & $3.60 \pm 0.40$ & 1.10 \\
\hline & & CTS & $2.50 \pm 0.20$ & $3.70 \pm 0.50$ & 1.20 \\
\hline \multirow[t]{2}{*}{ Median } & P-W & Controls & $1.72 \pm 0.17$ & $2.15 \pm 0.33$ & 0.43 \\
\hline & & CTS & $2.35 \pm 0.26$ & $3.39 \pm 0.43$ & 1.04 \\
\hline \multirow[t]{2}{*}{ Ulnar } & P-W & Controls & $1.67 \pm 0.10$ & $2.00 \pm 0.21$ & 0.33 \\
\hline & & CTS & $1.62 \pm 0.10$ & $2.25 \pm 0.22$ & 0.63 \\
\hline \multirow[t]{2}{*}{ PMU } & P-W & Controls & $0.045 \pm 0.157$ & $0.155 \pm 0.210$ & 0.111 \\
\hline & & CTS & $0.755 \pm 0.318$ & $1.145 \pm 0.394$ & 0.390 \\
\hline
\end{tabular}

CTS, carpal tunnel syndrome; SD, standard deviation; W-2, sensory antidromic wrist to finger 2; W-5, sensory antidromic wrist to finger 5; PMU, mixed palm-wrist latency difference median to ulnar; P-W, palm to wrist.

$2.00 \pm 0.21 \mathrm{~ms}$ in controls and to $2.25 \pm 0.22 \mathrm{~ms}$ in CTS patients. There was a highly significant difference between two groups in mean ulnar palmar latency $(p<0.0001)$.

The mean latency increase per $1{ }^{\circ} \mathrm{C}$ temperature reduction was $0.04 \mathrm{~ms}$ in controls and $0.10 \mathrm{~ms}$ in CTS patients for the median palm, and $0.03 \mathrm{~ms}$ in controls and $0.06 \mathrm{~ms}$ in CTS patients for the ulnar palm, both significant.

\section{DISCUSSION}

The central hypothesis of this study was based on our empiric observation that median and ulnar nerves in the same person can respond differently to temperature variation. By comparing latencies in the median nerve with those in the ipsilateral ulnar or radial nerve, it would be possible to reduce the effects of hand temperature on nerve conduction velocity. However, we found that in both controls and CTS patients there was an increase in PMU after cooling, consistent with our previous finding ${ }^{15}$. The increase was significantly greater in CTS patients versus controls. Lew et al. ${ }^{14}$ reported a latency increase of $0.06 \mathrm{~ms} /{ }^{\circ} \mathrm{C}$ for the median palmar $\left(0.10 \mathrm{~ms} /{ }^{\circ} \mathrm{C}\right.$ in ours) and $0.06 \mathrm{~ms} /{ }^{\circ} \mathrm{C}$ for the ulnar palmar (same of ours) in CTS patients. They showed that temperature did not significantly affect the latency differences or the CSI, results that were not confirmed by our current or previous findings ${ }^{15}$.

We are unable to provide a definitive explanation for the overreaction of median palm latencies to cooling. Because nerve-fiber diameters vary widely, nerve conduction velocities respond nonuniformly to temperature reduction ${ }^{10}$. A smaller temperature re- duction is required to block the action potentials of large-diameter A fibers versus $C$ fibers. If the large fibers, which react more to temperature reduction, were reduced in number in CTS patients, the PMU was expected to be reduced instead of increased. However, our finding of increased PMU may reflect the fact that in mild CTS there are more functional than structural nerve fiber abnormalities, i.e. without loss of large fibers; the slight longer latencies would be the result of the dispersion (compressive effects on the myelin) of the response and corresponding shift in peak.

Another puzzling and striking finding was that there was an overreaction of ulnar mixed palm latencies to cooling in only the CTS patients, suggesting that the ulnar nerve can also be stressed by a subclinical compression. Careful examination of the carpal tunnel and Guyon canal reveals an anatomical relationship. The floor of the Guyon canal (carpal ulnar neurovascular space) consists of the muscles of the hypothenar eminence, their fibers of origin, and the flexor retinaculum ${ }^{17}$. The retinaculum attaches to the radial and anterior surfaces of the hook of hamate. The stressed carpal transverse ligament could also stress the Guyon canal, and the ulnar nerve can occasionally be entrapped in this region ${ }^{17}$. Could the CTS symptoms in the entire hand, described in approximately $40-50 \%$ of patients ${ }^{18-20}$ be due to a subclinical compression of the ulnar nerve in the Guyon canal?

In conclusion, the overreaction of the mixed median palm latencies to cooling in CTS patients dramatically increased the PMU. To a lesser extent, mixed ulnar palm latencies also overreacted. We hypothesize 
that subclinical involvement of the ulnar nerve at the Guyon canal in CTS might explain symptomatology in all fingers. The PMU increase in CTS patients after cooling might be used to distinguish mild or incipient cases from normal cases, but further studies are needed to investigate this possibility. We could not confirm previous findings that latency differences between two nerves in the same hand are not influenced by temperature ${ }^{14}$.

\section{REFERENCES}

1. Dawson DM, Hallett M, Wilbourn AJ. Entrapment neuropathies, 3.Ed. Philadelphia: Lippincott-Raven; 1999.

2. Stewart JD. Focal peripheral neuropathies, 3.Ed. Philadelphia: Lippincott Willians \& Wilkins, 2000.

3. de Krom MC, Knipschild PG, Kester AD, Thijs CT, Boekkooi PF, Spaans F. Carpal tunnel syndrome: prevalence in the general population. J Clin Epidemiol 1992;45:373-376.

4. Atroshi I, Gummesson C, Johnsson R, Ornstein E, Ranstam J, Rosen I. Prevalence of carpal tunnel syndrome in a general population. JAMA 1999;282:153-158.

5. Stevens JC. AAEM minimonograph \#26: the electrodiagnosis of carpal tunnel syndrome. American Association of Electrodiagnostic Medicine. Muscle Nerve 1997;20:1477-1486.

6. Jablecki CK, Andary MT, Floeter MK, et al. Second AAEM literature review of the usefulness of nerve conduction studies and needle electromyography for the evaluation of patients with carpal tunnel syndrome. Muscle Nerve 2002;26(Suppl):S1-S53.

7. Bolton CF, Carter K, Koval JJ. Temperature effects on conduction studies of normal and abnormal nerve. Muscle Nerve 1982;5:145-147.
8. DeJesus PV, Hausmanowa-Petrusewicz I, Barchi RL. The effect of cold on nerve conduction of human slow and fast nerve fibers. Neurology 1973;23:1182-1189.

9. Denys EH. AAEM Minimonography \#14: the influence of temperature in clinical neurophysiology. Muscle Nerve 1991;14:795-811.

10. Dumitru D, Amato AA, Zwarts M. Electrodiagnostic Medicine, 2.Ed. Philadelphia: Hanley \& Belfus, 2002.

11. Oh SJ. Physiological factors affecting nerve conduction. In Oh SJ: Clinical Electromyography. Philadelphia: Lippincott Willians \& Wilkins, 2003:327-334.

12. Rutkove SB. Effects of temperature on neuromuscular electrophysiology. Muscle Nerve 2001;24:867-882.

13. Robinson LR, Micklesen PJ, Wang L. Strategies for analyzing nerve conduction data: superiority of a summary index over single tests. Muscle Nerve 1998;21:1166-1171.

14. Lew HL, Wang L, Robinson LR. Test-retest reliability of combined sensory index: implications for diagnosing carpal tunnel syndrome. Muscle Nerve 2000;23:1261-1264.

15. Kouyoumdjian JA, Ribeiro AT, Grassi LV, Spressão M. Infuence of temperature on comparative nerve conduction techniques for carpal tunnel syndrome diagnosis. Arq Neuropsiquiatr 2005;63:422-426.

16. Dioszeghy P, Stalberg E. Changes in sensory and motor nerve conduction parameters with temperature in normal and diseased nerve. Electroencephalogr Clin Neurophysiol 1992;85:229-235.

17. Cobb TK, Carmichael SW, Cooney WP. Guyon's canal revisited: an anatomic study of the carpal ulnar neurovascular space. J Hand Surg 1996;21A:861-869.

18. Kouyoumdjian JA. Síndrome do túnel do carpo: aspectos clínico-epidemiológicos em 668 casos. Arq Neuropsiquiatr 1999;57:202-207.

19. Stevens JC, Smith BE, Weaver AL, Bosch EP, Deen HG Jr, Wilkens JA. Symptoms of 100 patients with electromyographically verified carpal tunnel syndrome. Muscle Nerve 1999;22:1448-1456.

20. Stewart JD. Peripheral nerve fascicles: anatomy and clinical relevance. Muscle Nerve 2003;28:525-541. 